\title{
Effects of soil heat storage and phase shift correction on energy balance closure of paddy fields
}

\author{
Xiaoyin LIU, ${ }^{a}$ Shihong YANG, ${ }^{\text {a }}$ Junzeng XU, Jiangang $Z_{H A N G}{ }^{\mathrm{b}}$ and Jintao LIU ${ }^{\mathrm{a}}$ \\ ${ }^{a}$ State Key Laboratory of Hydrology-Water Resources and Hydraulic Engineering, Hohai University, 210098, Nanjing, \\ Jiangsu Province, People's Republic of China \\ ${ }^{b}$ Kunshan Water Conservancy Engineering Quality and Safety Supervision and Water Technology Popularization \\ Station, 215300, Kunshan, Jiangsu Province, People's Republic of China \\ *Corresponding author; ysh7731@hhu.edu.cn
}

Received: August 2, 2016; accepted: December 4, 2016

\begin{abstract}
RESUMEN
Se utilizó el método de covarianza eddy para medir los flujos de energía en un arrozal con ahorro de agua de riego en la Llanura del Sur de China, durante la etapa de crecimiento del arroz en 2013. También se analiza la respuesta del balance de energía superficial al cambio de almacenamiento térmico en el suelo entre las placas de flujo térmico enterradas a una profundidad específica y la superficie, y la corrección del desfase de los componentes del balance de energía, por medio de tres métodos estadísticos: mínimos cuadrados ordinarios (MCO), proporción del balance de energía (PBE) y remanente del balance de energía (D). Los resultados muestran que la curva de los MCO se incrementó $8.8 \%$ en promedio y el PBE medio diario aumentó $0.5 \%$ después de considerar el cambio en el almacenamiento térmico del suelo. El rango de las magnitudes de D registradas cada media hora varía de $-129-260 \mathrm{~W} \mathrm{~m}^{-2} \mathrm{a}-102-194 \mathrm{~W} \mathrm{~m}^{-2}$, y los valores absolutos de D decrecieron $9.9 \%$ en promedio. Tomando en cuenta la fase de corrección, el incremento en los coeficientes de regresión de los MCO (con un promedio de 11.3\%) y el decremento de D en las mediciones realizadas cada media hora (que van de -61 a $176 \mathrm{~W} \mathrm{~m}^{-2}$ ), ambos indicaron que la corrección de la fase de desplazamiento mejoró el cierre del balance de energía superficial en escalas de media hora, especialmente entre el amanecer y el mediodía, pero careció de utilidad en la escala diaria. Esto indica que ambos métodos son útiles para mejorar el grado del cierre del balance de energía, representado en diferentes escalas temporales con un índice de evaluación adecuado. Es necesario realizar investigaciones ulteriores que presten mayor atención a otros aspectos de la corrección.
\end{abstract}

\begin{abstract}
The eddy covariance technique was used to measure the energy fluxes of a paddy field under water-saving irrigation in the South China Plain for the stage of rice growth in 2013. This study analyzed the energy balance components and evaluated the energy balance closure. The study also discussed the response of surface energy balance to the change in soil heat storage between the heat flux plates buried at a specific depth and the surface, and the phase shift correction of energy balance components, by using three different statistical methods, namely ordinary least squares (OLS), energy balance ratio (EBR), and energy balance residual (D). The results showed that the OLS slope increased by an average of $8.8 \%$, and the mean daily EBR increased by $5.0 \%$ after considering the change in soil heat storage. The range of half-hourly $\mathrm{D}$ over a four-month period decreased from $-129-260 \mathrm{~W} \mathrm{~m}^{-2}$ to $-102-194 \mathrm{~W} \mathrm{~m}^{-2}$, and the absolute value of $\mathrm{D}$ decreased by $9.9 \%$ on the average. Considering the phase correction, the increase in OLS regression coefficients with an average of $11.3 \%$ and the decrease in half-hourly $\mathrm{D}$, ranging from -61 to $176 \mathrm{~W} \mathrm{~m}^{-2}$, both indicated that phase shift correction improved the surface energy balance closure at the half-hourly scale, specifically in the period from sunrise to noon, but had no use in the daily scale. Thus, the two correction methods are useful in improving the
\end{abstract}


degree of energy balance closure shown in different temporal scales with proper evaluation index. Moreover, further research should be given with more attention for other correction aspects.

Keywords: Water-saving irrigation, paddy field, eddy covariance, energy balance, soil heat storage, phase shift correction.

\section{Introduction}

The accurate determination of surface energy balance components in different terrestrial ecosystems is an essential prerequisite to understanding and modeling the interaction between ecosystems and ambient environments, which are linked with the hydrological cycle, climate change, plant productivity, and carbon budgets (Wilson et al., 2002; Castellvi et al., 2008; Bormann, 2011). Eddy covariance (EC) has been deemed as a preferred method for measuring surface energy flux and balance (Mauder et al., 2007). However, the lack of energy closure is unresolved, and a full guidance on experimental set up and raw data processing for the EC system is still unavailable. Typically, independent measurements of fluxes accounted for $70-90 \%$ of measured net radiation, as reported by studies in the last decade (Wilson et al., 2002; Jacobs et al., 2008; Leuning et al., 2012). Generally, the failure in the energy balance closure was attributed to the discrepancy of the source among various flux components; inhomogeneous surface cover and soil characteristics; flux divergence arising from transport that is multi-dimensional; the missed very low and/or high-frequency fluctuations of fluxes; turbulent dispersive fluxes; measurement errors related to the sensor separation; frequency response; alignment problems, and interference from tower or instrument-mounting structures (Cleugh and Roberts, 1994; Foken and Oncley, 1995; Laubach and Teichmann, 1999; Twine et al., 2000; Wilson et al., 2002; Masseroni et al., 2012).

The accurate estimations of surface soil heat flux and phase correction are both important aspects in improving surface energy closure for the results of the EC system. Soil heat flux $(G)$ measured at the soil surface was different than the underlying soil at a specific depth, and surface soil heat flux performed better in energy balance closure (Kustas et al., 2000; Heusinkveld et al., 2004; Russo, 2008; Yao et al., 2008; Masseroni et al., 2014, 2015). Thus, several methods were developed to estimate the surface soil heat flux $\left(G_{0}\right)$ based on soil heat flux measured by heat flux plates $\left(G_{s}\right)$. The first method is based on the phase delay in soil heat flux and temperature with the change in soil depth, or based on the principle that the amplitude of soil heat flux and temperature decay exponentially with the change in soil depth (van Wijk and de Vries, 1963; Heitman et al., 2010). The second method consists in analyzing ground temperature via the harmonic method with the insertion of heat flux plates at the surface, and calculating the soil thermal conductivity via the approximation method (Heusinkveld et al., 2004). In the third method, soil heat storage $(Q)$, calculated on the basis of soil temperature and moisture data, is integrated with the $G_{s}$ measured at a specific depth (Gao, 2005; Masseroni et al., 2015). This latter method is the one we have chosen.

Energy balance components and net radiation might vary out of synchronization with the 24-h daily cycle, which led to the systematic energy imbalance. Hence, phase correction was another important practice in improving the surface energy balance closure (Foken et al., 2006; Guo et al., 2008; Leuning et al., 2012; Sun et al., 2013; Wohlfahrt and Widmoser, 2013). Gao et al. (2010) presented a theoretical analysis of the phase difference in diurnal variation of soil surface temperature, soil temperature, soil surface heat flux, soil flux measured by heat flux plates, and soil heat storage, to examine the impact of the phase difference between soil surface heat flux and temperature on the surface energy closure; they concluded that the phase difference in soil surface heat flux vs. net radiation, sensible heat, and latent heat fluxes was an inherent source of soil surface energy imbalance. Guo et al. (2008) concluded that turbulent energy flux with forward phase displacement of about half an hour contributes to the energy balance closure about $1.4 \%-2.5 \%$ in a maize field. Li et al. (2008) reported that latent heat, sensible heat, and soil heat flux were half an hour lagging behind the net radiation in an alpine meadow. The slope of ordinary least squares (OLS) regression increased with a great improvement of $49.1 \%$, from 0.53 to 0.79 after phase shift correction. Leuning et al. (2012) concluded that the sum of eddy fluxes with half-hourly averages of sensible and latent heat was 
less than the available energy, and a substantial part of this underestimate could be explained by phase lags caused by incorrect estimates of the energy storage in soil, air, and biomass below the measurement height when the multisite data were analyzed.

Several indexes were used for evaluating energy balance closure, including energy balance ratio (EBR), linear regression coefficients (slope and intercept) from the OLS analysis, and energy balance residual (D). The most popular is EBR, which has the advantage of giving an overall evaluation of energy balance closure at longer time scales by averaging over random errors in the half-hourly measurements. A disadvantage of EBR is its potential to overlook biases in the half-hourly data, such as the tendency to overestimate positive fluxes during the day and underestimate negative fluxes at night (Wilson et al., 2002; Hiyama et al., 2007). The linear regression coefficients (slope and intercept) are determined from the OLS relationship between half-hourly estimates of the dependent turbulent flux variables against the independently derived available energy, which is technically valid only if there are no random errors in the independent variable (Li et al., 2005). D is another method for evaluating the degree of energy balance closure. Its advantage is that it could show the degree of energy imbalance at different time points (Cava et al., 2008). However, the value of D cannot reflect the differences in long-term data in energy balance after phase revision.

Paddy fields are one of the typical terrestrial ecosystems in the Asian monsoon region (Alberto et al., 2011), and the surface energy balance components measured in rice ecosystem are different from other crops because they are affected by the presence of water on the ground or the variation of soil moisture content (Tsai et al., 2007; Masseroni et al., 2015). However, most of the large amount of research on energy balance measurement and energy closure calculation has been conducted in ecosystems such as forests, grasslands, wetlands, and upland crop fields (Meyers and Hollinger, 2004; Castellvi et al., 2008; Cava et al., 2008; Oncley et al., 2007; Mauder et al., 2013; Masseroni et al., 2014), and few studies have been conducted in flooded rice paddy ecosystems (Oue, 2005; Castellvi et al., 2006; Tsai et al. 2007). With the increasing water scarcity, water saving irrigation (WSI) techniques were applied to rice paddies (Belder et al., 2004; Kato et al., 2011; Rothenberg et al., 2011; Uphoff et al., 2010), which exposed rice fields to drying-wetting cycles and greatly reduced seepage and evaporation losses (Bouman et al., 2007). In WSI conditions, energy balance in rice fields might be changed, but no results are available on energy balance measurement and energy closure calculation with the EC system in WSI paddy fields (Masseroni et al., 2014).

Thus, energy balance components in WSI paddy fields were measured with an EC system in South China. Three evaluation methods (EBR, D, and OLS regression coefficients) for the post-elaboration of energy balance closure were applied. The characteristics of energy balance fluxes were analyzed and discussed. The effects of soil heat storage and the displacement phase on the energy balance closure were moreover assessed with three evaluation indexes, and the performances of these indexes were discussed simultaneously in different temporal scales.

\section{Materials and methods}

\subsection{Site description}

The measurements were conducted using an EC system from July to October 2013, during the rice growth season, in paddy fields at the Kunshan irrigation and drainage experiment station $\left(31^{\circ} 15^{\prime} 15^{\prime \prime} \mathrm{N}\right.$, $\left.120^{\circ} 57^{\prime} 43^{\prime \prime} \mathrm{E}\right)$, in the Taihu Lake region of China. The study area has a subtropical monsoon climate, with an average annual temperature of $15.5^{\circ} \mathrm{C}$, annual precipitation of $1097.1 \mathrm{~mm}$, and annual evaporation of $1365.9 \mathrm{~mm}$. The mean annual relative humidity is $83 \%$, and the annual sunshine time is $2085.9 \mathrm{~h}$. The prevailing winds during the rice cultivation season are south-east trade winds. The experimental site is flat and fetched above $200 \mathrm{~m}$ in all directions. The soil is hydragric anthrosol, and the underlying paddy fields were irrigated with a local WSI practice named "controlled irrigation". In rice fields with controlled irrigation, the shallow flooding water is maintained in the re-greening stage or within 3-5 days after the application of pesticide and fertilizer; irrigation was applied only to saturate the soil without flooding in the rice growth period except the re-greening stage. The lower soil moisture thresholds for control irrigation were $70,65,60,70,75,80$, and $70 \%$ of the saturated soil moisture during the early tillering, middle tillering, later tillering, jointing, booting, earing to sprouting, and milk maturity stages, respectively, consistent with those given by Xu et al. (2012). 


\subsection{Instruments and measurements}

The EC tower (Open Path Eddy Covariance, OPEC) was composed of a Campbell CSAT3A sonic anemometer and an EC150 open-path infrared gas analyzer to measure the sensible heat flux $\left(H_{S}\right)$ and latent heat flux $(L E)$ with a $10 \mathrm{~Hz}$ observation rate. The sensors in the middle of the downwind portion of the field were aligned perpendicularly to the prevailing wind direction (south-east) to reduce flow interference. Net radiation $\left(R_{n}\right)$ was measured using a CNR4 radiometer (Kipp \& Zonen, Holland) at 1.5 $\mathrm{m}$ above ground. Soil heat flux $\left(G_{S}\right)$ was measured using HFP01SC heat flux plates (Campbell Scientific, USA) buried $8 \mathrm{~cm}$ beneath the ground. The volumetric water content of the surface soil layer $(0.1$, 0.2 , and $0.3 \mathrm{~m}$ ) was monitored using three CS616 soil moisture reflectometers (Campbell Scientific), and soil temperature was measured at depths of 0.1 , 0.2 , and $0.3 \mathrm{~m}$ below the soil surface by using three 109 TCAV-averaging soil thermocouple probes (Campbell Scientific). Table I shows the details of specific sensors on the EC system. At the same time, the half-hourly temperature, relative humidity, and precipitation data were recorded by an automatic meteorological station (WS-STD1, DELTA-T, UK) in the experiment station.

\subsection{Data processing}

EdiRe software was used to process raw EC $(10 \mathrm{~Hz})$ data as the covariance between turbulent fluctuations of the vertical wind speed and scalar mixing ratios. These were calculated by averaging the $30-\mathrm{min}$ blocks for quality assurance and quality control of the EC data (Oncley et al., 1993; Finnigan et al., 2003; Foken et al., 2012; Richardson et al., 2012; Mauder et al., 2013; Anderson and Wang, 2014), which included the coordinate rotation via the $2 \mathrm{D}$ rotation method (Anthoni et al., 2004), spectral loss correction (Moore, 1986; Masseroni et al., 2013), sonic virtual temperature conversion for sensible heat flux (Mauder et al., 2006), density fluctuations correction for latent heat flux (Ueyama et al., 2012), and spike detection (Vickers and Mahrt, 1997). In the spike detection algorithm, any value that exceeded the mean value \pm 3 times the standard deviations was labeled as a spike (Falge et al., 2001a), just as the values measured during the rain period or one hour before and after rain periods (Anderson and Wang, 2014). Moreover, flux data with friction velocity lower than the threshold friction velocity $u^{*}$ (which is equal to $0.1 \mathrm{~m} \mathrm{~s}^{-1}$, according to literature) was filtered out in data analysis to reduce data uncertainty (Massman and Lee, 2002; Li et al., 2005; Anthoni et al., 2004). Data gaps were then filled using linear interpolation for gaps shorter than $3 \mathrm{~h}$ and the mean diurnal average method in a window of 10 days for gaps longer than $3 \mathrm{~h}$ (Falge et al., 2001b).

\subsection{Energy balance equation and soil heat storage calculation}

Assuming that the energy converted into chemical energy by green plants and the horizontal flow of energy, caused by advection between the soil surface and the level of the eddy covariance instrumentation, were negligible; then the energy balance equation of a terrestrial surface is simplified as

$L E+H s=R_{n}-G-S$

where net radiation $\left(R_{n}\right)$, which is the external drive energy of the soil-plant-atmosphere continuum, is balanced by the sum of the latent $(L E)$ and sensible $(H s)$ heat fluxes to the air, soil heat flux $(G)$, and canopy heat storage in biomass and water content $(S)$. In the current research, $S$ was determined following the suggested procedure, in which $S$ was deduced from a

Table I. Specifications of the instruments or sensors of the eddy covariance system.

\begin{tabular}{llc}
\hline Measurement & Instrument or sensor & Location (m) \\
\hline $\mathrm{CO}_{2}$ and $\mathrm{H}_{2} \mathrm{O}$ concentrations & EC150, CSI, USA & 2.5 \\
Vertical wind speed & CSAT3A, CSI, USA & 2.5 \\
Net radiation & CNR4, Kipp \& Zonen, Netherlands & 1.5 \\
Soil heat flux & HFP01SC, Hukseflux, Netherlands & -0.08 \\
Air temperature and humidity & HMP155A, Vaisala, Finland & 2.0 \\
Soil temperature & 109, CSI, USA & $-0.1,-0.2,-0.3$ \\
Soil water content & TDR, CS616, CSI, USA & $-0.1,-0.2,-0.3$ \\
\hline
\end{tabular}


concentration profile method inside the canopy (Papale et al., 2006; Leuning et al., 2012) or based only on concentrations at the tower top (Meyers and Hollinger, 2004). In fact, $S$ was mostly neglected, specifically when the vegetation height was less than $8 \mathrm{~m}$ (Wilson et al., 2002). The present study found that $S$ was low and mostly fell in the range of -10 to $10 \mathrm{~W} \mathrm{~m}^{-2}$, with the concentration profile method that accounted for less than $2 \%$ of the available energy during the rice cultivation season (Leuning et al., 2012).

Surface soil heat flux $\left(G_{0}\right)$ was calculated as the sum of soil heat flux at a depth of $8 \mathrm{~cm}\left(G_{s}\right)$, change in energy storage $(Q)$ in the $8 \mathrm{~cm}$ soil layer, and change in energy storage in the flooding water $\left(G_{w}\right)$ in rice fields (Heusinkveld et al., 2004), which can be expressed as:

$G_{0}=Q+G_{s}+G_{w}$

where $G_{0}$ is the heat flux at soil surface $\left(\mathrm{W} \mathrm{m}^{-2}\right)$, $Q$ is the change in soil heat storage in the $8 \mathrm{~cm}$ soil layer $\left(\mathrm{W} \mathrm{m}^{-2}\right), G_{s}$ is the soil heat flux measured at 8 $\mathrm{cm}$ depth $\left(\mathrm{W} \mathrm{m}^{-2}\right)$, and $G_{w}$ is the change in energy storage in the flooding water $\left(\mathrm{W} \mathrm{m}^{-2}\right)$. Assuming that the soil was mostly non-flooded in water-saving irrigation paddy field, $G_{w}$ is neglected. $Q$ can be determined based on the change in soil temperature (Meyers and Hollinger, 2004; Heitman et al., 2010):

$Q=(\Delta T C s d) / \Delta t$

where $\Delta T$ is the change in soil temperature $\left({ }^{\circ} \mathrm{C}\right), C s$ is the heat capacity of the moist soil $\left(\mathrm{J} \mathrm{g}^{-1} \mathrm{~K}^{-1}\right), d$ is the soil thickness $(\mathrm{cm})$, and $\Delta t$ is the time step, which is equal to $30 \mathrm{~min}$. The air heat capacity is small compared with that of soil and water, and the volume fraction of soil organic matter is negligible; $C_{s}$ for moist mineral soils was written as (Masseroni et al., 2014; Kustas and Daughtry, 1990)

$C_{s}=\rho_{b} C_{d}+\theta_{\imath} \rho_{w} C_{w}$

where $\rho_{b}$ is the bulk density $\left(1.35 \mathrm{~g} \mathrm{~cm}^{-3}\right), \rho_{w}$ is the density of water $\left(1.0 \mathrm{~g} \mathrm{~cm}^{-3}\right), C_{w}$ is the heat capacity of water $\left(4.190 \mathrm{~J} \mathrm{~kg}^{-1} \mathrm{~K}^{-1}\right)$, and $\theta_{v}$ is the volumetric soil water content. $C_{d}$ is the heat capacity of a dry mineral soil, which is $840 \mathrm{~J} \mathrm{~kg}^{-1} \mathrm{~K}^{-1}$ (Hanks and Ashcroft, 1980).

\subsection{Energy balance closure analysis}

Energy balance closure was evaluated using three different methods. The first method was to derive linear regression coefficients (slope and intercept) from the OLS relationship between the half-hourly estimates of the dependent flux variables $(L E+H s)$ against the independently derived available energy $\left(R_{n}-G\right)$ (Wohlfahrt and Widmoser, 2013), which can be expressed as:

$L E+H s=a\left(R_{n}-G\right)+b$

where $a$ is the slope of linear repression, and $b$ is the intercept of linear repression. The ideal closure is represented by an intercept of zero and the slope of 1 .

The second alternative method to evaluate energy closure is the EBR, which was calculated based on the cumulative sum of $\left(R_{n}-G\right)$ and $(L E+H s)$ over sepcific time periods (Gu et al., 1999; Wilson et al., 2002).

$E B R=\frac{L E+H s}{R_{n}-G}$

$D$ is as another method of evaluating the degree of energy balance closure. The energy balance residuals presented in this study are defined as (Wohlfahrt and Widmoser, 2013; Cava et al., 2008):

$D=R_{n}-G-H s-L E$

If the value of $D$ is more than zero, then the surface energy supply is greater than the outlay; otherwise, the result is opposite.

\section{Results and discussions}

\subsection{Energy balance components and energy balance} closure

The diurnal variations of monthly averaged energy balance components varied in a unimodal shape (Fig. 1). Usually, the values of $R_{n}, G_{s}, L E$ and $H s$ gradually decreased with decreasing solar radiation from July to October. Compared with $H s$ and $G_{s}$, the diurnal variation amplitude of $L E$ was much greater. The $L E$ flux was the main component of net radiation, and the function of $G_{s}$ and $H s$ was relatively low, with a similar amount in the energy balance. Hence, the estimation of evapotranspiration is the most important process in determining the exchanges of energy and mass in a paddy field. 


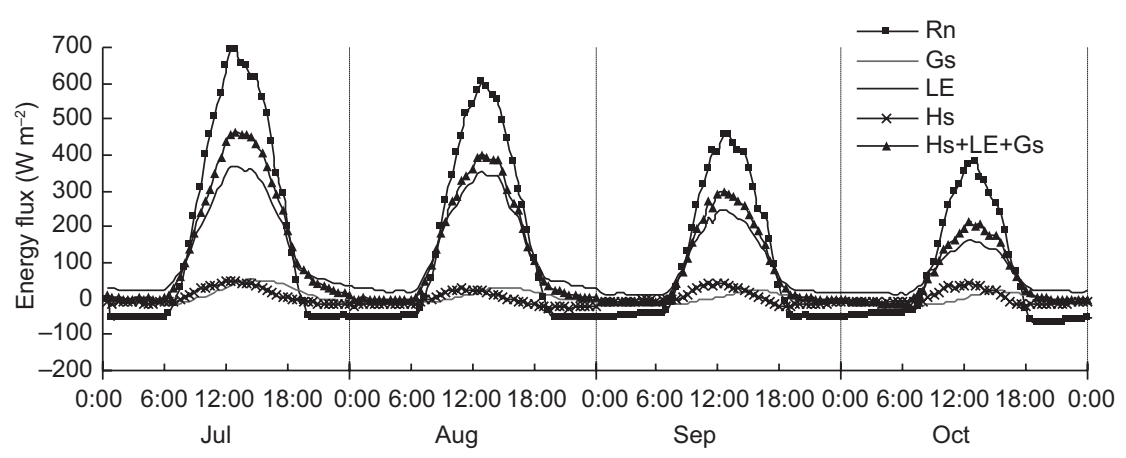

Fig. 1. Monthly averaged diurnal variations of energy balance components during the rice cultivation season.

Ideal energy balance closure can be achieved only when the available energy is equal to the turbulent fluxes. However, the energy balance at the earth's surface could not be achieved with experimental data since the late 1980s (Mauder et al., 2007; Ochsner et al., 2007; Foken, 2008). In the current research, a gap existed between $R_{n}$ and the sum of $L E, H s$, and $G_{s}$. The OLS regression between the half-hourly estimates of the dependent flux variables $(L E+H s)$ and the independently derived available energy $\left(R_{n}-\right.$ $G_{s}$ ) is plotted in Figure 2 by using 5616 half-hourly samples. The regression was significant at a $0.1 \%$ confidence level, with a slope of 0.57 , an intercept of $37.93 \mathrm{~W} \mathrm{~m}^{-2}$, and a coefficient of determination $\left(R^{2}\right)$ of 0.92 . The mean daily EBR (Eq. 6) was calculated as 0.87 , ranging from 0.61 to 1.37 . Figure 3 shows that most of the daily EBR slightly fluctuated at the stage of earlier growth. During the later stage, daily EBR varied significantly and sometimes it was higher than 1 . The half-hourly D data (Eq. 7) ranged from -129 to $260 \mathrm{~W} \mathrm{~m}^{-2}\left(14.1 \mathrm{~W} \mathrm{~m}^{-2}\right.$ in average). Figure 1

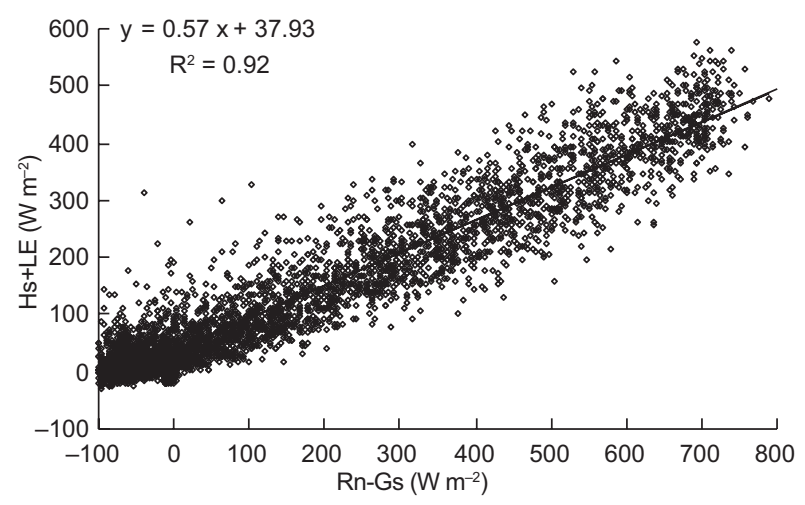

Fig. 2. Linear regression analysis of energy balance characteristics without considering changes in soil heat storage during the rice cultivation season. shows that monthly averaged $L E, H s$, and $G_{s}$ varied diurnally in the same pattern as $R_{n}$ but with several phase differences. The turbulent fluxes lagged behind $R_{n}$ about half an hour, and the hysteresis of $G_{s}$ was more obvious, at about $1.5-2 \mathrm{~h}$, whether the time of peak or the time of curve mutation appeared.

The heat stored in the soil between the heat flux plates buried at $8 \mathrm{~cm}$ and the soil surface might account for the poor energy closure, as well as the phase shift between the irradiation and the other fluxes. Energy balance components should be measured at the same balance layer when calculating the energy balance. In fact, those energy balance components were measured with different balance layers via diverse methods. $R_{n}$ was measured at $1.5 \mathrm{~m}$ above ground; the turbulent fluxes $(H s+L E)$ were measured approximately $2.5 \mathrm{~m}$ above ground; $G_{s}$ was measured $8 \mathrm{~cm}$ below the soil surface. Moreover, energy transmission from the surface to the heat flux plate through the thickness of the soil takes some time and the heat flux plate measurement of the change also requires a particular response time (Poblete-Echeverría et al., 2014). Hence, it can be concluded that the different balance layers of measurement and the difference in the rate of heat transference have a significant impact on the energy balance closure (Berliner et al., 2004; Oncley et al., 2007).

\subsection{Influence of soil heat storage on the energy ba- lance closure}

The surface soil heat flux $G_{0}$ was calculated by incoporating the soil heat storage on the $G_{s}$ measured at a depth of $8 \mathrm{~cm}$ with Eq. (2). $G_{0}$ varied from -39.6 to $118.8 \mathrm{~W} \mathrm{~m}^{-2}$ during the rice growth season (Fig. 4), which was larger than the $G_{s}$ measured at a depth of $8 \mathrm{~cm}\left(-18.8\right.$ to $\left.52.6 \mathrm{~W} \mathrm{~m}^{-2}\right)$. The maximum and 


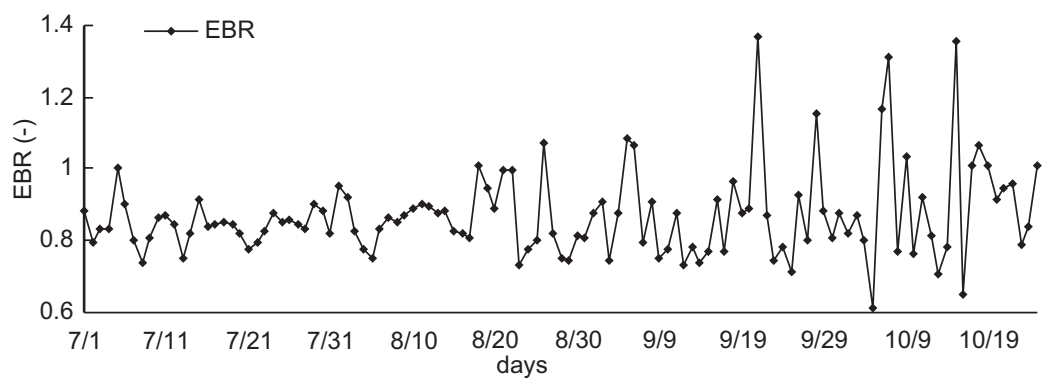

Fig. 3. Variations of the energy balance radio without considering changes in soil heat storage during the rice cultivation season.

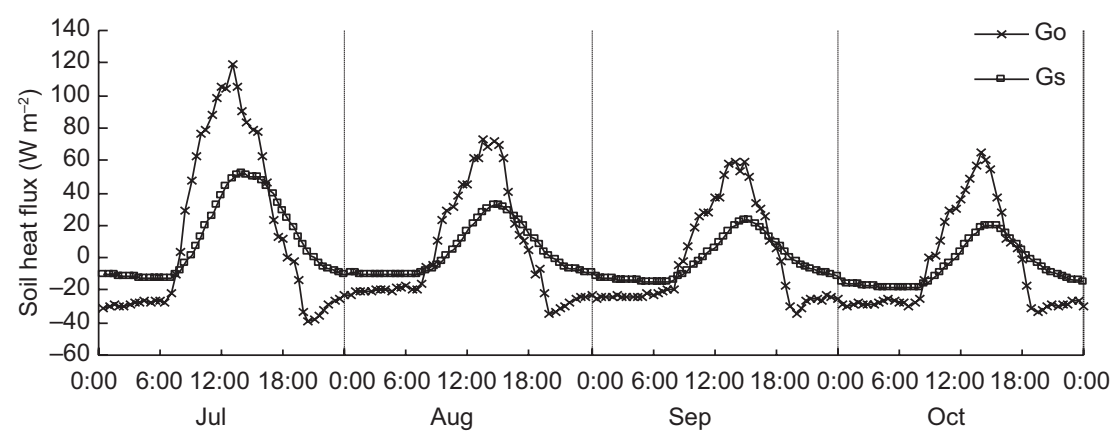

Fig. 4. Monthly averaged diurnal variations of measured soil heat flux at $8 \mathrm{~cm}$ depth $\left(G_{s}\right)$ compared with calculated value at the surface $\left(G_{0}\right)$.

average differences were about 66.2 and $46.9 \mathrm{~W} \mathrm{~m}^{-2}$, respectively. Figure 4 also indicates that a phase shift difference existed between $G_{0}$ and $G_{s}$. $G_{s}$ frequently varied at a $0.5-1.5$ hours lag behind $G_{0}$. This is in good agreement with the results of Masseroni et al. (2015), who found that soil heat flux at the soil surface $\left(G_{0}\right)$ reached daily maximum and minimum values of about 200 and $-100 \mathrm{~W} \mathrm{~m}^{-2}$, respectively, which presented a wider amplitude than soil heat flux without considering soil heat storage $(Q)$ (from -30 to $90 \mathrm{~W} \mathrm{~m}^{-2}$ in the case of the intermittent irrigation treatment of rice field). In addition, the peak of $G_{s}$ was phase-lagged 1.5-3 h compared with the peak of $R_{n}$. Thus, the change in soil heat storage between the soil surface and the soil heat flux plates buried at 8 $\mathrm{cm}$ was not negligible in the energy balance calculation. Qualifying the impact of correction in the value and phase of soil storage flux on the energy balance closure in paddy fields is therefore significant.

Energy balance closure was evaluated via three different methods, by incorporating the change in soil heat storage. Considering the change in heat storage, the slope and intercept of the OLS regression were 0.62 and $31.28 \mathrm{~W} \mathrm{~m}^{-2}$, respectively (Fig. 5), which increased by $8.8 \%$ in slope and decreased by $17.5 \%$ compared with the results in Figure 2. The daily EBR with soil heat storage correction (Fig. 6) varied almost in the same way as described in Figure 3. The daily EBR varied between 0.70 and 1.32 , with an average of 0.91 , and increased by $5.0 \%$. The half-hourly D ranged from -102 to $194 \mathrm{~W} \mathrm{~m}^{-2}$, with an average of $12.7 \mathrm{~W} \mathrm{~m}^{-2}$. Therefore, the change in heat storage between the heat flux plates buried at $8 \mathrm{~cm}$ and the surface has a significant impact on the energy

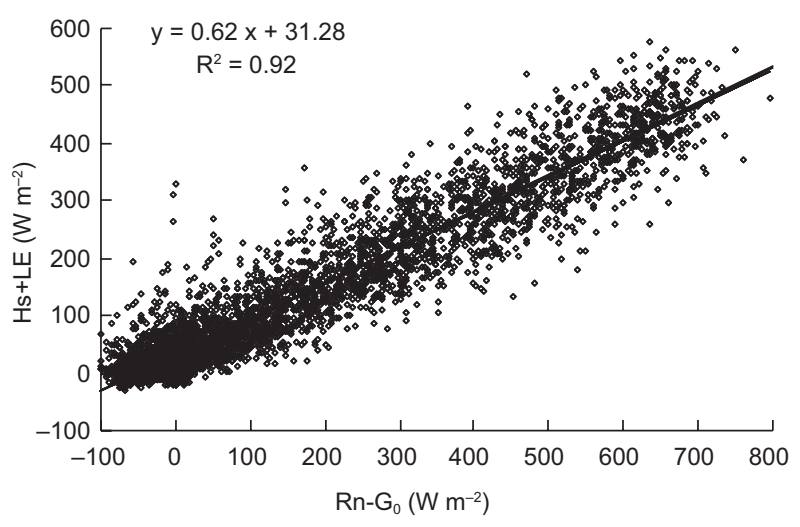

Fig. 5. Linear regression analysis of energy balance characteristics considering changes in soil heat storage during the rice cultivation season. 


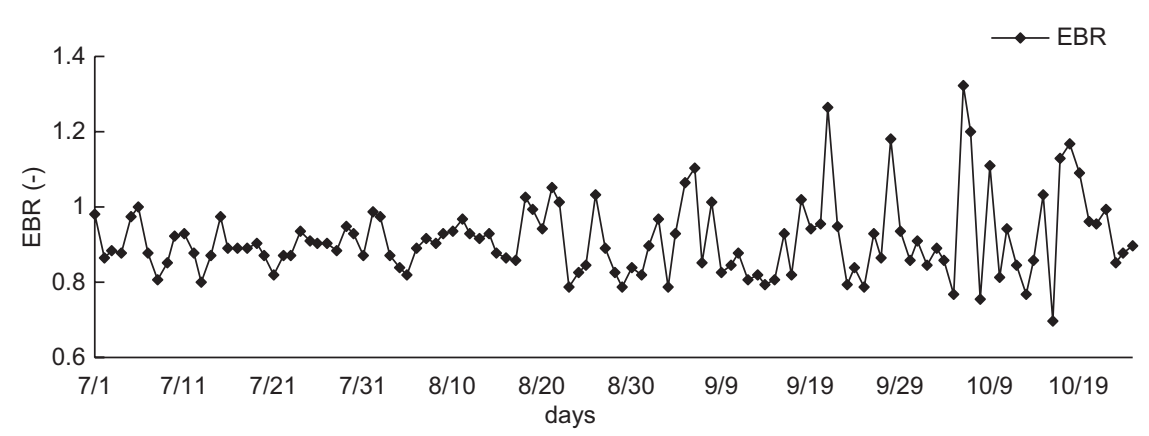

Fig. 6. Variation of the energy balance ratio considering changes in soil heat storage during the rice cultivation season.

balance closure, which should not be neglected in relevant studies (Mauder et al., 2007; Wohlfahrt and Widmoser, 2013).

\subsection{The effects of phase displacement on energy balance closure.}

The impact of phase shift of the observed $H s, L E$, and $G_{0}$ on the surface energy balance closure was analyzed with three indexes. For the period with net radiation higher than $1, H s, L E$, and $G_{0}$ were adjusted by phase correction to allow the daily accumulated maximum value to appear at the same time as the maximum accumulated $R_{n}$. The OLS regression between $H s+L E$ against the available energy $\left(R_{n}-\right.$ $G_{0}$ ) with phase shift correction was calculated and plotted in Figure 7. The slope of regression was 0.69 , with a significant improvement at a $0.1 \%$ confidence level, intercept of 23.14, and $R^{2}$ of 0.891 . Compared with the raw data without any correction, the slope of the OLS regression increased by $21.1 \%$. The mean daily EBR was also calculated as 0.91 and varied in the same pattern as Figure 6. The value of half-hourly

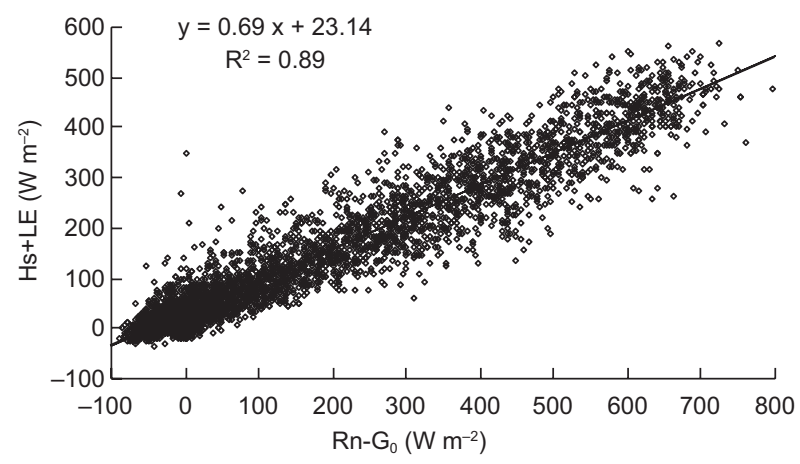

Fig. 7. Linear regression analysis OLSs with phase shift correction during the rice cultivation season.
D ranged from -61 to $176 \mathrm{~W} \mathrm{~m}^{-2}$. Compared with the results of the soil heat storage correction but without phase shift correction, the slope of regression increased by $11.3 \%$, however, the daily EBR (0.91) and daily $\mathrm{D}\left(12.7 \mathrm{~W} \mathrm{~m}^{-2}\right)$ were the same. Therefore, these statistical indexes had different results in the evaluation of the performance of phase shift correction in the daily energy balance closure.

\subsection{Comparison and analysis of energy balance clo- sure in different temporal scales}

The daily EBR and daily averaged D calculated at a daily scale were not suitable for evaluating the performance improvement of the phase correction. Diurnal variations of half-hourly EBR and half-hourly D were calculated and plotted in Figures 8 and 9 to analyze the effect of phase displacement on the energy balance closure in a half-hourly temporal scale.

Figure 8 indicates that the half-hourly EBR was negative during nighttime and positive during daytime. Comparing the two figures, there was a general increase in the half-hourly EBR from sunrise to noon after phase shift correction but it appeared almost identical in the afternoon with a value of about 1 around 16:00. This phenomenon might be explained by the continuous increase in air and soil temperature with the increase in net radiation during the morning; hence, energy transmission from net radiation to other energy fluxes was expended at some time. Temperature was relatively stable in the afternoon; therefore, the energy balance ratio was high (close to 1) with good atmospheric stability. The EBR drastically changed during the morning and evening transition periods, both before and after the phase shift correction, mainly because the temperature changed quickly and the atmospheric turbulent exchange was not 

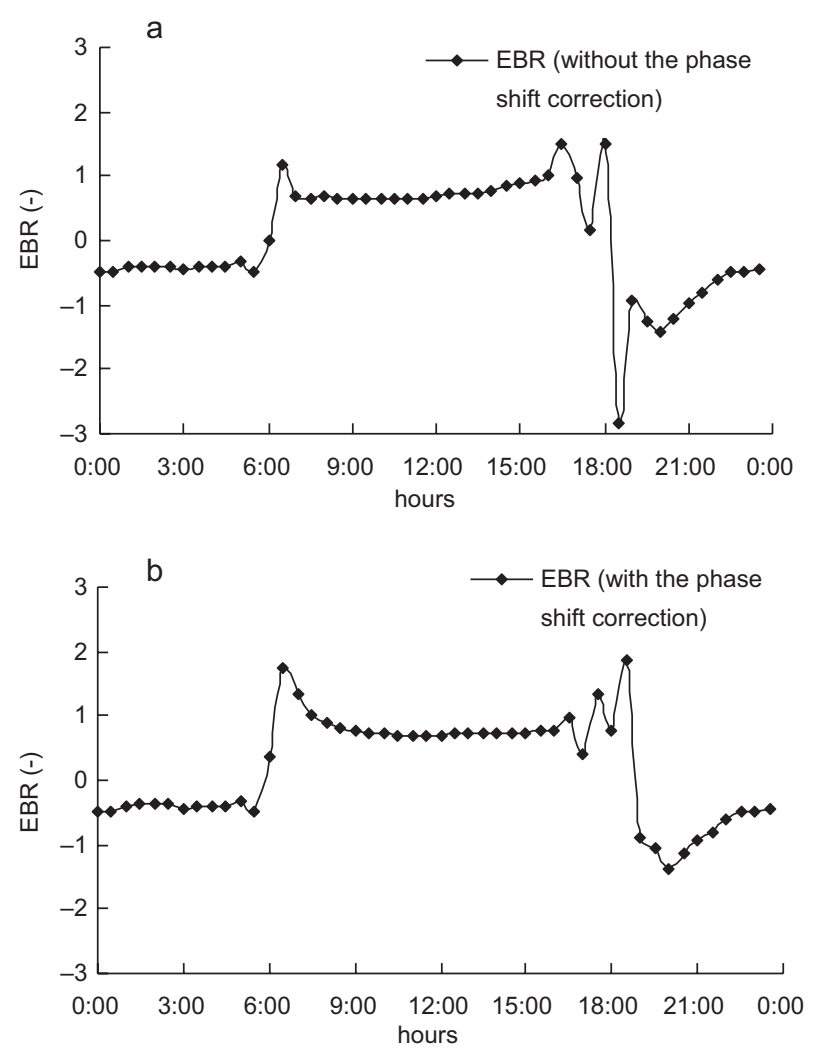

Fig. 8. Diurnal variation of EBR during the rice cultivation season, 2013. (a) Without phase shift correction. (b) With phase shift correction.

stable neither above nor beneath the canopy during these two periods. The high velocity of vertical exchange in the stratosphere exceeded the normal range of variation. Thus, capturing the variable data at a frequency of $10 \mathrm{~Hz}$ with high accuracy was difficult for EC systems. Furthermore, the value of EBR was negative in the night regardless of whether the phase shift correction was performed or not, which meant that the turbulent energy fluxes were positive and much higher than the available energy. The methods of half-hourly EBR were unavailable for the evaluation of the energy balance closure during nighttime. The degree of energy balance closure was calculated, but the nighttime data was excluded. The EBR that involved the use of daytime data sets was smaller than daily EBR with the whole-day observation data, regardless of whether phase shift correction was performed, and the result was consistent with those of Leuning et al. (2012). The energy entering the soil, air, and biomass during the daytime was returned partly during nighttime, hence, the energy distribution and conversion of the paddy field presented a specific compensation effect during the day and night. Whole-day observations were numerous and comprehensive, which meant that energy transmission was a continuous process, and that research regarding energy components needs also to be spatially and temporally continuous.

The monthly averaged value of half-hourly D varied in the unimodel curve (Fig. 9). During transition periods at morning or evening, $R_{n}$ was as low as zero, and $\mathrm{D}$ was almost zero. Besides those two transition periods, D was always positive in daytime and negative during nighttime. The half-hourly energy balance residual was calculated $(i)$ without any correction $\left(D_{l}\right),(i i)$ only considering the change in soil heat storage $\left(D_{2}\right)$, and (iii) considering both change in soil heat storage and phase correction $\left(D_{3}\right)$. Figure 9 indicates that the absolute value of $D_{3}$ was

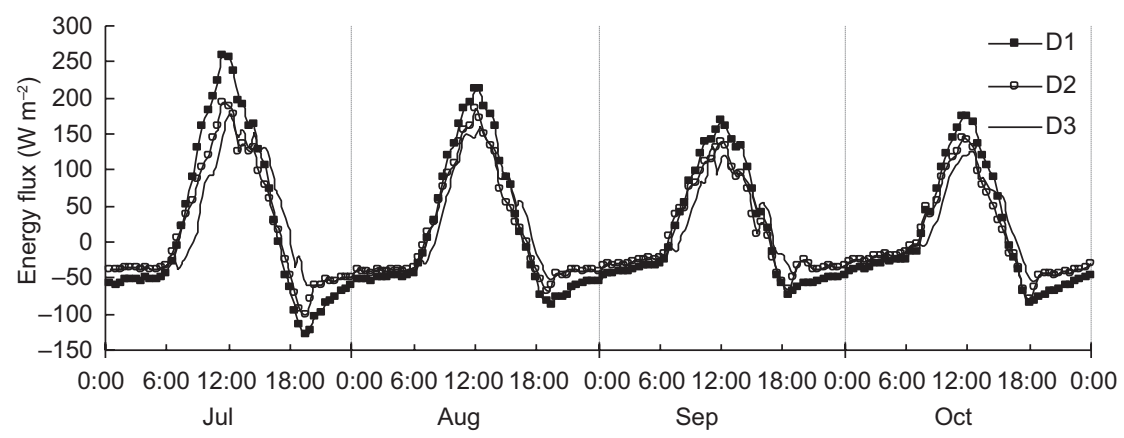

Fig. 9. Monthly averaged diurnal variations of $D_{1}, D_{2}$ and $D_{3}$ during the rice cultivation season in 2013. $D_{1}$ is the energy balance residual without any correction, $D_{2}$ is the energy balance residual without the forward phase shift but considering the change in soil heat storage, and $D_{3}$ is the energy balance residual considering the change in soil heat storage as well as the forward phase shift. 
significantly less than $D_{2}$ and $D_{1}$ during the period from 7:00 to $12: 30$ as well as during nighttime, but more or less than $D_{2}$ and $D_{1}$ from 12:30 to 17:00. The absolute value of $D_{2}$ was smaller than $D_{1}$ throughout the whole period, which meant that the correction of soil heat storage improved the energy balance closure in whole day periods, and the correction of phase shift improved the energy balance closure during the heating period from sunset to noon, which is the same as the results from half-hourly EBR. The two half-hourly indexes indicated that the hysteresis of energy conversion occurred mainly during the morning, and the synchronization of energy components improved with increasing net radiation. The results of this study show that with the use of net radiation peak time we could infer the delaying time periods of energy components and correct the phase shift according to different periods.

This analysis showed that the effect of phase shift correction was reflected in the whole-day process. Thus, correction was also a significant method to improve the surface energy balance closure at half-hourly scale with the indexes of OLS regression, diurnal variations of half-hourly EBR, and half-hourly $\mathrm{D}$, even though the daily accumulation values of half-hourly data were the same with and without phase shift correction. The correction methods of soil heat storage and phase displacement are different in principle and action, which means both are useful to improve the surface energy balance closure in different temporal scales with a proper evaluation index.

Aside from the two temporal scales, further analysis of EBR in this paddy field found that the value of daily EBR (0.91) was greater than the growth-stage EBR (0.88) with the two corrections, and no significant effect existed for the degree of growth-stage energy balance closure with and without the two corrections. Thus, it is reasonable to conclude that the greater imbalance in growth-stage scale was caused by the following reasons:

1. The sampling problems, i.e., the footprint area of EC measurements may not match with the source area of net radiometer and soil heat flux measurements. With the rice development over the whole growing stage, the height difference between the canopy and the sensors height greatly varied, which may cause the footprint area to be beyond the boundary of the EC field; consequently, lack of energy balance closure may occur.

2. Neglecting other energy sinks, such as canopy heat storage, biochemical energy storage transformed by photosynthesis, energy transforming in the meteorological process, and energy exchange arising from advection may also lead to the more obvious lack of energy balance closure in the growth-stage scale. Thus, more attention should be given to further observations and research on these aspects.

\section{Conclusions}

The EC technique was used to measure energy fluxes over a water-saving irrigation paddy field in the South China Plain for the rice growth stage in 2013. The diurnal variations of monthly averaged energy balance components varied in a unimodel shape, however the value and phase gaps ranged between $R_{n}$ and the sum of $L E, H s$, and $G_{s}$. The accuracy of the soil heat storage term estimation has a crucial role on the improvement of energy balance closure. Considering the heat storage between the heat flux plates buried at $8 \mathrm{~cm}$ and the surface, the OLS slope for the half-hourly data set increased by an average of $8.8 \%$, and the daily EBR increased by $5.0 \%$. The range of half-hourly D over the whole growth stage decreased from $-129-260 \mathrm{~W} \mathrm{~m}^{-2}$ to $-102-194 \mathrm{~W} \mathrm{~m}^{-2}$, and the absolute value decreased by $9.9 \%$. The phase shift correction was also a significant method to improve the surface energy balance closure at a half-hourly scale. Compared to the results with change of soil heat storage but without phase shift correction, the OLS regression slope increased by $11.3 \%$, and the half-hourly D diminished, ranging from -61 to $176 \mathrm{~W}$ $\mathrm{m}^{-2}$, even though the daily EBR and D were the same. Moreover, both half-hourly EBR and D indicated that the hysteresis of energy conversion occurred mainly during the morning. Thus, the indexes of OLS, EBR, and $\mathrm{D}$, with different principle and action, had different applications and variation degrees of response to the correction of energy balance closure in different temporal scales.

The results of this paper have general application in the correction of energy balance deficits. WSI is a promising water-saving technology being developed to lower water requirements of rice fields, in order to address issues of water scarcity; it has been popularized and applied in large areas, especially 
in Southeast Asia (e.g., China, South Korea and the Philippines). Thus, the soil heat storage and phase shift correction proposed in this research are necessary for the accurate estimation of evapotranspiration in WSI rice fields. In addition, our results are useful for understanding the applicability of evaluation indexes and the process of water and energy flux exchange at different temporal scales under a WSI practice, which provides an essential support for further development of the WSI theory and technology. More attention should be given to future research on additional causes of the energy balance deficit (e.g. sampling problems and neglecting other energy sinks, and long-term continuous measurement using the EC system is needed to establish a coupled model of water and energy flux in future studies.

\section{Acknowledgements}

This research was financially supported by the National Natural Science Foundation of China (No. 51209066, 51579070), the Fundamental Research Funds for Central Universities (No. 2014B17114, 2015B34514), the China Postdoctoral Science Foundation (No. 2013T60495), the Innovative Young Scholar Project of State Key Laboratory of Hydrology-Water Resources and Hydraulic Engineering (No. 20145027912), the Priority Academic Program Development of Jiangsu Higher Education Institutions, and the Advanced Science and Technology Innovation Team in Colleges and Universities in Jiangsu Province.

\section{References}

Alberto M., R. Wassmann, T. Hirano, A. Miyata, R. Hatano, A. Kumar, A. Padre and M. Amante, 2011. Comparison of energy balance and evapotranspiration between flooded and aerobic rice fields in the Philippines. Agr. Water Manag. 98, 1417-1430, doi:10.1016/j. agwat.2011.04.011.

Anderson R. G. and D. Wang, 2014. Energy budget closure observed in paired Eddy Covariance towers with increased and continuous daily turbulence. Agric. For. Meteorol. 184, 204-209, doi:10.1016/j. agrformet.2013.09.012.

Anthoni P. M., A. Freibauer, O. Kolle and E.-D. Schulze, 2004. Winter wheat carbon exchange in Thuringia, Germany. Agric. For. Meteorol. 121, 55-67, doi:10.1016/ S0168-1923(03)00162-X.
Belder P., B. A. M. Bouman, R. Cabangon, L. Guoan, E. J. P. Quilang, Y. H. Li, J. H. J. Spiertz and T. P. Tuong, 2004. Effect of water-saving irrigation on rice yield and water use in typical lowland conditions in Asia. Agr. Water Manag. 65, 193-210, doi:10.1016/j. agwat.2003.09.002.

Berliner P. R., A. Zangvil and E. Ben-Dor, 2004. Soil water evaporation during the dry season in an arid zone. J. Geophys. Res.-Atmos. 109(D16), doi:10.1029/ 2004JD004802.

Bormann H., 2011. Sensitivity analysis of 18 different potential evapotranspiration models to observed climatic change at German climate stations. Climatic Change. 104, 729-753, doi:10.1007/s10584-010-9869-7.

Bouman B. A. M., R. M. Lampayan and T. P. Tuong, 2007. Water management in irrigated rice: Coping with water scarcity. Los Baños (Philippines). International Rice Research Institute, $54 \mathrm{pp}$.

Castellvi F., A. Martínez-Cob and O. Pérez-Coveta, 2006. Estimating sensible and latent heat fluxes over rice using surface renewal. Agric. For. Meteorol. 139, 164169, doi:10.1016/j.agrformet.2006.07.005.

Castellvi F., R. L. Snyder and D. D. Baldocchi, 2008. Surface energy-balance closure over rangeland grass using the eddy covariance method and surface renewal analysis. Agric. For. Meteorol. 148, 147-1160, doi:10.1016/j.agrformet.2008.02.012.

Cava D., D. Contini, A. Donateo and P. Martano, 2008. Analysis of short-term closure of the surface energy balance above short vegetation. Agric. For. Meteorol. 148, 82-93, doi:10.1016/j.agrformet.2007.09.003.

Cleugh H. A. and T. Roberts, 1994. Local-scale energy balances and microclimate in the desert ranges of central Australia. Aust. Meteorol. Mag. 43, 219-228.

Falge E., P. Anthoni, M. Aubinet, C. Bernhofer, G. Burba, R. Ceulemans, R. Clement, H. Dolman, A. Granier, P. Gross, T. Grünwald, D. Hollinger, N. O. Jensen, G. Katul, P. Keronen, A. Kowalski, L. Chun Ta, B. E. Law, T. Meyers, J. Moncrieff, E. Moors, J. W. Munger, K. Pilegaard, Ü. Rannik, C. Rebmann, A. Suyker, J. Tenhunen, K. Tu, S. Verma, T. Vesala, K. Wilson, S. Wofsy, D. Baldocchi and R. Olson, 2001a. Gap filling strategies for defensible annual sums of net ecosystem exchange. Agric. For. Meteorol. 107, 43-69, doi:10.1016/S0168-1923(00)00225-2.

Falge E., D. D. Baldocchi, R. Olson, P. Anthoni, M. Aubinet, C. Bernhofer, G. Burba, R. Ceulemans, R. Clement, H. Dolman, A. Granier, P. Gross, T. Grünwald, D. Hollinger, N-O. Jensen, G. Katul, P. Keronen, 
A. Kowalski, C. Ta Lai, B. E. Law, T. Meyers, J. Moncrieff, E. Moors, J. W. Munger, K. Pilegaard, Ü. Rannik, C. Rebmann, A. Suyker, J. Tenhunen, K. Tu, S. Verma, T. Vesala, K. Wilson and S. Wofsy, 2001b. Gap filling strategies for long term energy flux data sets. Agric. For. Meteorol. 107, 71-77, doi:10.1016/ S0168-1923(00)00235-5.

Finnigan J., R. Clement, Y. Malhi, R. Leuning and H. Cleugh, 2003. A re-evaluation of long term flux measurement techniques part I: averaging and coordinate rotation. Bound-Lay. Meteorol. 107, 1-48, doi:10.1023/A:1021554900225.

Foken T. and S. P. Oncley, 1995. A report on the workshop: instrumental and methodological problems of land-surface flux measurements. Bull. Am. Meteorol. Soc. 76, 1191-1193.

Foken T., F. Wimmer, M. Mauder, C. Thomas and C. Liebethal, 2006. Some aspects of the energy balance closure problem. Atmos. Chem. Phys. 6, 4395-4402, doi:10.5194/acp-6-4395-2006.

Foken T., 2008. The energy balance closure problem: an overview. Ecol. Appl. 18, 1351-1367, doi:10.1890/06-0922.1.

Foken T., R. Leuning, S. P. Oncley, M. Mauder and M. Aubinet, 2012. In: Eddy covariance: A practical guide to measurement and data analysis (M. Aubinet, T. Vesala and D. Papale, Eds.). Springer, Dordrecht, pp. 85-132.

Guo J. X., L. G. Bian and Y. J. Dai, 2008. Analysis of surface energy balance closure in different temporal scales and study on the imbalance reasons over a maize field. Science in China (Series D) 38, 1103-1111.

Gao Z., 2005. Determination of soil heat flux in a Tibetan short-grass prairie. Bound-Lay. Meteorol. 114, 165178, doi:10.1007/s10546-004-8661-5.

Gao Z., R. Horton and H. P. Liu, 2010. Impact of wave phase difference between soil surface heat flux and soil surface temperature on soil surface energy balance closure. J. Geophys. Res.-Atmos. 115, D16112, doi:10.1029/2009JD013278.

Gu J., E. A. Smith and J. D. Merritt, 1999. Testing energy balance closure with GOES-retrieved net radiation and in situ measured eddy correlation fluxes in BOREAS. J. Geophys. Res. 104, 27881-27893, doi:10.1029/ 1999JD900390.

Hanks R. J. and G. L. Ashcroft, 1980. Applied soil physics: Soil water and temperature applications. Springer, Berlin, 159 pp.

Heitman J. L., R. Horton, T. J. Sauer, T. S. Ren and X. Xiao, 2010. Latent heat in soil heat flux measurements.
Agric. For. Meteorol. 150, 1147-1153, doi:10.1016/j. agrformet.2010.04.017.

Heusinkveld B. G., A. F. G. Jacobs, A. A. M. Holtslag and S. M. Berkowicz, 2004. Surface energy balance closure in an arid region: role of soil heat flux. Agric. For. Meteorol. 122, 21-37, doi:10.1016/j.agrformet.2003.09.005.

Hiyama T., M. A. Strunin, H. Tanaka and T. Ohta, 2007. The development of local circulations around the Lena River and their effect on tower-observed energy imbalance. Hydrol. Process. 21, 2038-2048, doi:10.1002/hyp.6705. Jacobs A., B. Heusinkveld and A. Holtslag, 2008. Towards closing the surface energy budget of a mid-latitude grassland. Bound-Lay. Meteorol. 126, 125-136, doi:10.1007/s10546-007-9209-2.

Kato Y., A. Henry, D. Fujita, K. Katsura, N. Kobayashi and R. Serraj, 2011. Physiological characterization of introgression lines derived from an indica rice cultivar, IR64, adapted to drought and water-saving irrigation. Field Crop. Res. 123, 130-138, doi:10.1016/j. fcr.2011.05.009.

Kustas W. and C. Daughtry, 1990. Estimation of the soil heat fluxnet radiation ratio from spectral data. Agric. For. Meteorol. 49, 205-223, doi:10.1016/01681923(90)90033-3.

Kustas W., J. D. Albertson, A. T. Cahill and T. M. Scanlon, 2000. Application of radiometric temperature observations for energy balance estimation over agricultural sites in the Little Washita during SGP99 Experiment. Proceedings of the International Geoscience and Remote Sensing Symposium (IGARSS), vol. 3. pp.1072-1074.

Laubach J. and U. Teichmann, 1990. Surface energy budget variability: A case study over grass with special regard to minor inhomogeneities in the source area. Theor. Appl. Climatol. 62, 9-24, doi:10.1007/ s007040050070.

Leuning R., E. van Gorsel, W. J. Massman and P. R. Isaac, 2012. Reflections on the surface energy imbalance problem. Agric. For. Meteorol. 156, 65-74, doi:10.1016/j.agrformet.2011.12.002.

Li Q., X. Z. Zhang, P. L. Shi, Y. T. He, L. L. Xu and W. Sun, 2008. Study on the energy balance closure of Alpine meadow on Tibetan Plateau. Journal of Natural resources 23, 391-399.

Li Z., G. Yu, X. Wen, L. Zhang, C. Ren and Y. Fu, 2005. Energy balance closure at China FLUX sites. Science in China Series D: Earth Sciences 48, 51-62.

Masseroni D., G. Ravazzani, C. Corbari and M. Mancini, 2012. Turbulence integral length and footprint 
dimension with reference to experimental data measured over maize cultivation in Po Valley, Italy. Atmósfera 25, 183-198.

Masseroni D., G. Ercolani, C. Corbari and M. Mancini, 2013. Accuracy of turbulent flux measurements through the use of high frequency data by eddy covariance tower: The case study of Landriano (PV), Italy. Ital. J. Agrometeorol. 3, 5-12.

Masseroni D., C. Corbari and M. Mancini, 2014. Limitations and improvements of the energy balance closure with reference to experimental data measured over a maize field. Atmósfera 27, 335-352, doi:10.1016/ S0187-6236(14)70033-5.

Masseroni D., A. Facchi, M. Romani, E. A. Chiaradia, O. Gharsallah and C. Gandolfi, 2015. Surface energy flux measurements in a flooded and an aerobic rice field using a single eddy-covariance system. Paddy Water Environ. 13, 405-424, doi:10.1007/s10333014-0460-0.

Massman W. J. and X. Lee, 2002. Eddy covariance flux corrections and uncertainties in long-term studies of carbon and energy exchanges. Agric. For. Meteorol. 113, 121-144, doi:10.1016/S0168-1923(02)00105-3.

Mauder M., C. Liebethal, M. Göckede, J. P. Leps, F. Beyrich and T. Foken, 2006. Processing and quality control of flux data during LITFASS-2003. BoundLay. Meteorol. 121, 67-88, doi:10.1007/s10546-0069094-0.

Mauder M., S. P. Oncley, R. Vogt, T. Weidinger, L. Ribeiro, C. Bernhofer, T. Foken, W. Kohsiek, H. A. R. de Bruin and $\mathrm{H}$. Liu, 2007. The energy balance experiment EBEX-2000. Part II: Intercomparison of eddy-covariance sensors and post-field data processing methods. Bound-Lay. Meteorol. 123, 29-54, doi:10.1007/ s10546-006-9139-4.

Mauder M., M. Cuntz, C. Drüe, A. Graf, C. Rebmann, H. P. Schmid, M. Schmidt and R. Steinbrecher, 2013. A strategy for quality and uncertainty assessment of long-term eddy covariance measurements. Agric. For. Meteorol. 169, 122-135, doi:10.1016/j.agrformet.2012.09.006.

Meyers T. and S. Hollinger, 2004. An assessment of storage terms in the surface energy balance of maize soybean. Agric. For. Meteorol. 12, 105-115, doi:10.1016/j.agrformet.2004.03.001.

Moore C. J., 1986. Frequency response corrections for eddy correlation systems. Bound-Lay. Meteorol. 37, 17-35, doi:10.1007/BF00122754.

Ochsner T. E., T. J. Sauer and R. Horton, 2007. Soil heat storage measurements in energy balance studies.
Agron. J. 99, 311-319, doi:10.2134/agronj2005.0103S.

Oncley S., A. Delany, T. Horst and P. Tans, 1993. Verification of flux measurement using relaxed eddy accumulation. Atmos. Environ. 27, 2417-2426, doi:10.1016/0960-1686(93)90409-R

Oncley S. P., T. Foken, R. Vogt, W. Kohsiek, H. A. R. Debruin, C. Bernhofer, A. Christen, E. van Gorsel, D. Grantz, C. Feigenwinter, I. Lehner, C. Liebethal, H. Liu, M. Mauder, A. Pitacco, L. Ribeiro and T. Weidinger, 2007. The energy balance experiment EBEX-2000. Part I: overview and energy balance. Bound-Lay. Meteorol. 123, 1-28, doi:10.1007/ s10546-007-9161-1.

Oue H., 2005. Influences of meteorological and vegetation factors on the partitioning of the energy of a rice paddy field. Hydrol. Process. 19, 1567-1583, doi:10.1002/ hyp. 5589 .

Papale D., M. Reichstein, M. Aubinet, E. Canfora, C. Bernhofer, W. Kutsch, B. Longdoz, S. Rambal, R. Valentini, T. Vesala and D. Yaki, 2006. Towards a standardized processing of net ecosystem exchange measured with eddy covariance technique: Algorithms and uncertainty estimation. Biogeosciences 3, 571-583, doi:10.5194/ bg-3-571-2006.

Poblete-Echeverría C., D. Sepúlveda-Reyes and S. Ortega-Farías, 2014. Effect of height and time lag on the estimation of sensible heat flux over a drip-irrigated vineyard using the surface renewal (SR) method across distinct phenological stages. Agric. Water Manage. 141, 74-83, doi:10.1016/j.agwat.2014.04.006.

Richardson A. D., M. Aubinet, A. G. Barr, D. Y. Hollinger, A. Ibrom, G. Lasslop and M. Reichstein, 2012. Uncertainty quantification. In: Eddy covariance: A practical guide to measurement and data analysis (M. Aubinet, T. Vesala and D. Papale, Eds.). Springer Dordrecht, pp. 173-210.

Rothenberg S. E., X. Feng, B. Dong, L. Shang, R. Yin and $X$. Yuan, 2011. Characterization of mercury species in brown and white rice (Oryza sativa L) grown in water-saving paddies. Environ. Pollut. 159, 1283-1289, doi:10.1016/j.envpol.2011.01.027.

Russo A. E., 2008. The reliability of surface renewal technique to estimate evapotranspiration fluxes of different crops: Applications in Sicily and California. Ph.D. Thesis, Ingegneria Agraria XXI ciclo, Università degli Studi di Catania.

Sun T., Z. H. Wang, and G. H. Ni, 2013. Revisiting the hysteresis effect in surface energy budgets. Geophys. Res. Lett. 40, 1741-1747, doi:10.1002/grl.50385. 
Tsai J., B. Tsuang, P. Lu, M. Yao and Y. Shen, 2007. Surface energy components and land characteristics of a rice paddy. J. Appl. Meteorol. 46, 1879-1900, doi:10.1175/ 2007JAMC1568.1.

Twine T. E., W. P. Kustas, J. M. Norman, D. R. Cook, P. R. Houser, T. P. Meyers, J. H. Prueger, P. J. Starks and M. L. Wesely, 2000. Correcting eddy-covariance flux underestimates over a grassland. Agric. For. Meteorol. 103, 279-300, doi:10.1016/S01681923(00)00123-4.

Ueyama M., R. Hirata, M. Mano, K. Hamotani, Y. Harazono, T. Hirano, A. Miyata, K. Takagi and Y. Takahashi, 2012. Influences of various calculation options on heat, water and carbon fluxes determined by open- and closed-path eddy covariance methods. Tellus B 64, 1-26, doi:10.3402/tellusb.v64i0.19048.

Uphoff N., A. Kassam and R. Harwood, 2010. SRI as a methodology for raising crop and water productivity: productive adaptations in rice agronomy and irrigation water management. Paddy Water Environ. 9, 3-11, doi:10.1007/s10333-010-0224-4.

Van Wijk W. R. and D. A. de Vries, 1963. Periodic temperature variations in a homogeneous soil. In: Physics of Plant Environment (W. R. van Wijk (Ed.). North-Holland Publishing, Amsterdam, pp. 102-143.
Vickers D. and L. Mahrt, 1997. Quality control and flux sampling problems for tower and aircraft data. J. Atmos. Ocean. Tech. 14, 512-526, doi:10.1175/1520-0426(1997)014<0512:QCAF$\mathrm{SP}>2.0 . \mathrm{CO} ; 2$.

Wilson K., A. Goldstein, E. Falge, M. Aubinet, D. Baldocchi, P. Berbigier, C. Bernhofer, R. Ceulemans, H. Dolman, C. Field, A. Grellej, A. Ibromk, B. E. Lawl, A. Kowalski, T. Meyers, J. Moncrieff, R. Monson, W. Oechelo, J. Tenhunen, R. Valentini and S. Verma, 2002. Energy balance closure at FLUXNET sites. Agric. For. Meteorol. 113, 223-243, doi:10.1016/ S0168-1923(02)00109-0.

Wohlfahrt G. and P. Widmoser, 2013. Can an energy balance model provide additional constraints on how to close the energy imbalance? Agric. For. Meteorol. 169, 85-91, doi:10.1016/j.agrformet.2012.10.006.

Xu J., S. Peng, S.Yang and W. Wang, 2012. Ammonia volatilization losses from a rice paddy with different irrigation and nitrogen managements. Agric. Water Manage. 104, 184-192, doi:10.1016/j.agwat.2011.12.013.

Yao J. M., L. Zhao, Y. J. Ding, L. L. Gu, K. Q. Jiao, Y. P. Qiao and Y.X. Wang, 2008. The surface energy budget and evapotranspiration in the Tanggula region on the Tibetan Plateau. Cold Reg. Sci. Technol. 52, 326-340, doi:10.1016/j.coldregions.2007.04.001. 